\title{
INTEGRASI KETERAMPILAN 4C DALAM MODUL TEORI BELAJAR DAN PEMBELAJARAN FISIKA
}

\author{
Ni Putu Ayu Hervina Sanjayanti, '., Putu Wina Yasa Pramadi²., \\ 1,2)Universitas Pendidikan Ganesha \\ e-mail: ${ }^{1)}$ sanjayantihervina@gmail.com \\ 2) winayasapramadi@gmail.com
}

\begin{abstract}
Abstrak
Belum adanya bahan ajar inovatif yang dapat memfasilitasi mahasiswa dalam belajar menyebabkan mahasiswa mengalami kesulitan memahami materi perkuliahan. Selain itu mahasiswa juga merasa cepat bosan dan kurang termotivasi dalam mengikuti perkuliahan Tujuan dari penelitian ini adalah untuk mengembangkan dan menguji modul teori belajar dan pembelajaran fisika yang terintegrasi pada keterampilan abad ke-21 yang berfokus pada keterampilan 4C melalui Research and Development (R\&D). Penelitian ini dilakukan kepada mahasiswa semester dua tahun akademik 2019/2020 Prodi Pendidikan Fisika Undiksha.Teknik pengumpulan data melalui observasi dan pemberian kuesioner dan intrumen pengumpulan data menggunakan instrumen kuesioner dan lembar observasi. Teknik analisis data penelitian ini menggunakan teknik analisis data kuantitatif dan teknik analisis data kualitatif. Hasil penelitian memperlihatkan rekapitulasi aspek-aspek penilaian dari berbagai valiadasi ahli, dosen Metodologi penelitian,lembar kuesioner mahasiswa, dan lembang observasi. Berikut merupakan persentasenya: kelayakan modul yang meliputi hasil validasi ahli materi sebesar $61.3 \%$ (kategori baik); hasil validasi ahli media sebesar $75.8 \%$ (kategori baik sekali); hasil evaluasi diri modul oleh dosen sebesar $90 \%$ (kategori baik sekali); hasil lembar observasi uji coba lapangan sebesar $78.9 \%$ (kategori baik sekali); dan hasil lembar kuesioner mahasiswa sebesar 76.3\% (kategori baik sekali). Maka modul teori belajar dan pembelajaran fisika yang terintegrasi keterampilan $4 \mathrm{C}$ ini layak digunakan dalam proses perkuliahan.
\end{abstract}

Kata kunci: keterampilan 4C, modul, teori belajar dan pembelajaran fisika

The absence of innovative teaching materials that can facilitate students in learning causes students to have difficulty understanding lecture material. In addition, students also feel bored quickly and are less motivated in attending lectures. The aim of this research is to develop an integrated learning theory and physics learning module on 21 st century skills that focus on $4 \mathrm{C}$ skills. It aims to find out the suitable of this module as teaching material for students in the Prodi Pendidikan Fisika Undiksha. This research method used research and development (R\&D). The research procedure was divided into two, namely preparation and implementation. This research was conducted to students in the three semester of the academic year 2019/2020 Prodi Prodi Pendidikan Fisika Undiksha. Data collection techniques used questionnaire and observation sheets as instrument. This research data analysis technique used quantitative data analysis techniques and qualitative data analysis techniques. The results showed the recapitulation of assessment aspects from various experts, learning theory and physics learning lecturer, student questionnaire sheets, and observations sheet. The following are the percentages of the result module eligibility which includes: the results of the material expert validation was $61.3 \%$ (good category); the results of the validation of media experts was $75.8 \%$ (excellent category); module self-evaluation results by lecturers was $90 \%$ (excellent category); field trial observation sheet results was 78.9\% (excellent category); and the results of the student questionnaire sheet was $76.3 \%$ (excellent category). So the learning theory and physics learning module which is integrated with $4 \mathrm{C}$ skills is appropriate to be used in the learning process.

Keywords: $4 \mathrm{C}$ skills, module, learning theory and physics learning

\section{Pendahuluan}

Terujinya kualitas sistem pendidikan pada abad kreatif ini sangat dirasakan oleh pendidik. Para pendidik diharapkan mampu menghasilkan luaran/ lulusan yang penuh dengan kreatifitas guna mampu bersaing dalam mengarungi ketatnya persaingan dunia. Dalam UU 
No 12 Tahun 2012 tentang Pendidikan Tinggi merumuskan kewajiban dosen menulis buku ajar atau buku teks, yang diterbitkan oleh Perguruan Tinggi dan/atau publikasi ilmiah sebagai salah satu sumber belajar dan untuk pengembangan budaya akademik. Kerangka pembelajaran abad 21 menyatakan bahwa kebutuhan peserta didik selain pengetahuan harus menyeimbangkan keterampilan untuk berhasil dalam pekerjaan, kehidupan dan kewarganegaraan (p21.org; Wrahatnolo and Munoto: 2018).

Abad ke-21, teknologi dan informasi mempengaruhi setiap aspek kehidupan. Abad yang dikenal sebagai transformasi masyarakat industri menjadi masyarakat berpengetahuan. Hal itu membuat orang dengan mudah memperkaya pengetahuan mereka melalui internet. Ini juga membuat mereka mudah mengakses informasi dari seluruh dunia. Namun, perkembangan ini berdampak buruk bagi masyarakat dan lingkungan. Informasi yang tersebar di seluruh dunia tidak terkendali dan menyebabkan ledakan digital yang tinggi. Akibatnya, orang mengalami kesulitan dalam memilah informasi yang mereka butuhkan. Mereka dapat memilah antara sumber tepercaya, tipuan atau opini. Guna mempersiapkan pelajar abad ke-21 untuk menjadi pelajar yang handal di masa depan, pendidik di seluruh dunia mempromosikan beberapa keterampilan untuk menghadapi tantangan perkembangan abad ke-21. Oleh karena itu, pelajar membutuhkan keterampilan abad ke - 21 yang disingkat sebagai 4C yaitu critical thinking (berpikir kritis), collaboration (kolaborasi), creativity (kreatifitas), dan communication (komunikasi) (Mahanal, 2009: 20).

Menurut Ozturk and Degiztanlionglu (2018) pengemasan bahan ajar sangat diharapkan guna mengaktifkan pengajaran. Florence Martin (2011) mengungkapkan dalam para pendesain pembelajaran agar mengembangkan dan mendesain pembelajaran sesuai dengan komunitas lingkungan. Bahan ajar merupakan segala bahan yang disusun secara sistematis, menampilkan sosok utuh dari kompetensi yang akan dikuasai peserta didik (Prastowo, 2011). Mata Kuliah teori belajar di Prodi Pendidikan Fisika Undiksha merupakan mata kuliah yang wajib ditempuh oleh seluruh mahasiswa dan sebagai sentral potensi untuk mengembangkan keterampilan mahasiswa, sesuai dengan ketetapan perumusan KKNI bahwa outcome mata kuliah ini berupa produk proposal/ karya ilmiah mahasiswa. Menurut Dantes (2012) metodologi merupakan ilmu yang mempelajari cara-cara melakukan penelitian. Menurut Cohen., Manion \& Marison (2007) metodologi bertujuan untuk menjawab suatu fenomena hingga dapat mencapai atau menarik suatu kesimpulan, sedangan Ary, Jacobs, Lucy (2010) menguraikan metodologi menguraikan metode penelitian deduktif dan induktif dan menggambarkan hubungan suatu variabel dalam skala hipotesis.

Kondisi saat ini pada mata kuliah teori belajar dan pembelajaran fisika di Prodi Pendidikan Fisika Undiksha belum maksimalnya bahan ajar generik yang telah digunakan untuk kebutuhan peserta didik, baik untuk melatih cara berfikir maupun digunakan dalam menghadapi tugas akhir. Hal ini terlihat dari hasil wawancara dengan dosen pengampu terdahulu serta hasil dari penilian proses dan produk yang dihasilkan. Kehadiran bahan pengajaran generik yang digunakan dalam pembelajaran selama ini belum mampu mendongkrak pemikiran kritis, hal ini terlihat dari aktivitas mahasiswa yang kurang Latar belakang penelitian tidak lebih dari 500 kata yang berisi latar belakang dan permasalahan yang akan diteliti, tujuan khusus, dan urgensi penelitian. Pada bagian ini perlu dijelaskan uraian tentang spesifikasi khusus terkait dengan skema. adanya kereatifitas dalam dalam menulis baik dalam memuliskan ide, berargumen, studi analisis maupun komunikasi yang sangat kurang efektif. Padahal keterampilan tersebut yang harus diberikan pada mahasiswa guna mewujudkan pembelajaran abad 21. Bahan ajar yang akan dikembangkan dalam kajian ini akan menyematkan keterampilan belajar dan Berinovasi keterampilan Abad 21 yaitu (1) Critical Thinking, (2) Comunication, (3) Collaboration dan (4) Creativity (Triling dan Fadell, 2009). Keterampilan berpikir kritis, keterampilan penting dimiliki oleh peserta didik dalam menemukan sumber masalah dan bagaimana mencari seta menemukan solusi atas masalah yang dihadapi. Keterampilan berkomunikasi, keterampilan untuk mengungkapkan pemikiran, gagasan, pengetahuan, ataupun informasi baru yang (NEA, 2010). Keterampilan berkolaborasi merupakan keterampilan untuk bekerja bersama secara efektif dan menunjukkan rasa hormat pada tim yang beragam, (Greenstein, 2012). Keterampilan berpikir 
kreatif (Creative Thinking Skills) keterampilan, yang berhubungan dengan keterampilan menggunakan pendekatan yang baru untuk menyelesaikan suatu permasalahan, inovasi, dan penemuan (Abdullah dan Osman, 2010). Penelitian ini bertujuan untuk mengetahui kelayakan bahan ajar metodologi penelitian dari aspek konten, bahasa, desain dan mengetahui kelayakan bahan ajar pada uji coba kelompok. Urgensi penelitian ini akan secara langsung menjawab kebutuhan para peserta didik akan bahan ajar yang mengembangkan 4 keterampilan yang harus mereka miliki.

\section{Metode}

Metode penelitian ini adalah research and development (R\&D) yang digunakan untuk memproduksi produk baru dankemudian menguji keefektifan produk (Sugiyono, 2012: 409). Produk penelitian ini berupa modul mata kuliah metodologi penelitian yang terintegrasi dengan keterampilan 4C abad ke-21 untuk mahasiswa TK semester 3 di PGG tahun akademik 2019/2020.

Ada beberapa langkah-langkah pengembangan modul (Sungkono, dkk,2003: 10), yaitu: 1) Tahap perencanaan; 2)Tahap penulisan: persiapan outline (menentukan topic dan sub - sub topik) dan penulisan (menulis draft, tes, penilaian hasil belajar); 3) Tahap review, uji coba, dan revisi; dan 4) Tahap finalisasi dan pencetakan. Secara garis besar dalam penilitian ini disimpulkan ada dua tahap dalam prosedur penelitian ini, yaitu tahap persiapan penelitian dan tahap implementasi penelitian. Tahap persiapan berisi kegiatan berupa persiapan awal, perizinan penelitian, dan persiapan instrument penelitian. Tahap kedua berisi kegiatan berupa melihat potensi dan masalah, desain produk, validasi ahli, evaluasi diri produk, revisi produk, uji coba lapangan, revisi produk, dan produk akhir.

Instrumen yang digunakan dalam penelitian ini berupa kuesioner dan lembar observasi untuk mengumpulkan data. Teknik analisis data penelitian ini menggunakan teknis analisis data kuantitatif dan teknik analisis data kualitatif.

\section{Hasil dan Pembahasan}

A. Uji Kelayakan Modul

Modul yang dikembangkan berupa modul teori belajar dan pembelajaran fisika. Komponenkomponen dalam penyusunan modul metodologi ini yaitu sampul, kata pengantar, daftar isi, glossarium, indikator pencapaian dan tujuan, materi, contoh kasus, rangkuman, latihan, dan daftar pustaka. Modul ini memiliki latihan - latihan yang mengandung keterampilan creative thinking, communication, collaboration, dan creativity. Setelah modul ini didesain, selanjutnya modul divalidasi oleh para ahli yaitu ahli materi, media dan pembelajaran.

\section{B. Validasi Ahli Materi}

Validasi ahli materi dilakukan oleh dua ahli. Penilaian yang dilakukan meliputi penilaian kualitas modul metodologi dengan memberikan kuesioner dan draft modul. Ada empat aspek penilaian yang akan dinilai oleh validator di dalam kuesionar, yaitu aspek kelayakan isi, aspek kelayakan penyajian, aspek penilaian bahasa, dan aspek penilaian berbasis $4 \mathrm{C}$.

Hasil validasi kelayakan isi dapat dilihat pada table dan diagram berikut.

Table 1. Skor Aspek Kelayakan Isi

\begin{tabular}{lcccc}
\hline \multicolumn{1}{c}{ Kriteria Penilaian } & Ahli 1 & Ahli 2 & Total skor & Rata - Rata Skor \\
\hline Sangat Baik (SB) & 38.1 & 9.5 & 47.6 & 23.8 \\
Baik (B) & 57.1 & 61.9 & 119.1 & 59.5 \\
Kurang (K) & 4.8 & 28.6 & 33.4 & 16.7 \\
Sangat Kurang (SK) & 0 & 0 & 0 & 0 \\
\hline
\end{tabular}


Untuk lebih jelasnya Persentase kelayakan isi modul dapat juga dilihat pada diagram 1 berikut.

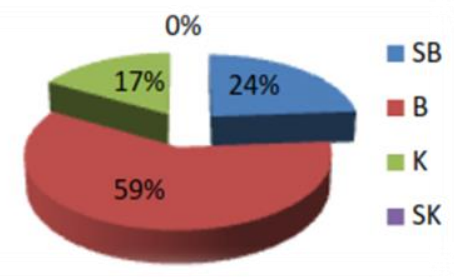

\section{Diagram 1. Persentase kelayakan isi modul}

Berdasarkan diagram 1, dapat dilihat persentase kelayakan isi modul yang termasuk kategori sangat baik (SB) $24 \%$, baik (B) 59\%, kurang (K) $17 \%$, dan sangat kurang (SK) 0\%. Maka jika dilihat dari persentase yang terbesar untuk kelayakan isi modul adalah kategori baik (B) sebesar $59 \%$.

Aspek selanjutnya adalah aspek penilaian berbasis 4C. berikut merupakan Tabel hasil lembar kuesioner aspek penilaian modul berbasis 4C dari validator.

Tabel 2 penilaian modul berbasis $4 \mathrm{C}$

\begin{tabular}{ccccc} 
Kriteria Penilaian & Validator 1 & Validator 2 & Jumlah & Rata - Rata Skor \\
\hline Sangat Baik (SB) & 25 & 50 & 75 & $\mathbf{2 5}$ \\
Baik (B) & 75 & 50 & 125 & $\mathbf{6 2 . 5}$ \\
Kurang (K) & 0 & 0 & 0 & $\mathbf{0}$ \\
Sangat Kurang (SK) & 0 & 0 & 0 & $\mathbf{0}$
\end{tabular}

Untuk lebih jelasnya persentase penilaian modul berbasis $4 \mathrm{C}$ dapat juga dilihat pada diagram 2 berikut.

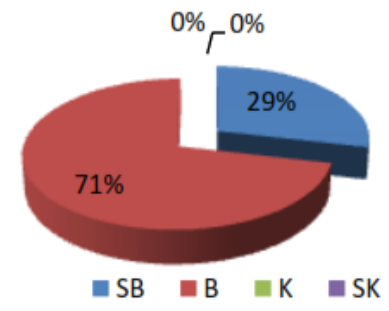

Diagram2. persentase penilaian modul berbasis $4 \mathrm{C}$

Berdasarkan diagram persentase penilaian 4C, dapat dilihat persentase penilaian 4C sebagai berikut: persentase kategori sangat baik (SB) sebesar 29\%,persentese kategori baik (B) sebesar $71 \%$, persentase kategori kurang $(\mathrm{K})$ sebesar $0 \%$, dan persentase kategori sangat kurang (SK) sebesar 0\%. Maka jika dilihat dari persentase yang terbesar untuk penilaian berbasis 4C adalah kategori baik (B) sebesar $71 \%$.

C. Evaluasi Diri Modul

Kegiatan evaluasi diri ini berupa evaluasi yang dilakukan oleh dosen mata kuliah metodologi penelitian terhadap modul. Dosen diberikan kuesioner dan draft modul, kemudian mengevualuasi dengan mengisi kuesioner.

Hasilnya dapat dilihat sebagai berikut. 
Tabel 3. Tabel Hasil Evaluasi Diri

\begin{tabular}{lcccc}
\hline ASPEK PENILAIAN & SS & S & TS & STS \\
\hline Aspek Tampilan & 0 & 6 & 0 & 0 \\
Aspek Penyajian Materi & 0 & 8 & 2 & 0 \\
Aspek Manfaat & 0 & 4 & 0 & 0 \\
\hline Jumlah & $\mathbf{0}$ & $\mathbf{1 8}$ & $\mathbf{2}$ & $\mathbf{0}$
\end{tabular}

Berdasarkan hasil validasi ahli, evaluasi diri modul oleh dosen, hasil uji coba lapangan berupa hasil lembar observasi dan hasil lembar kuesioner mahasiswa, dapat dilihat dalam diagram 3 berikut:

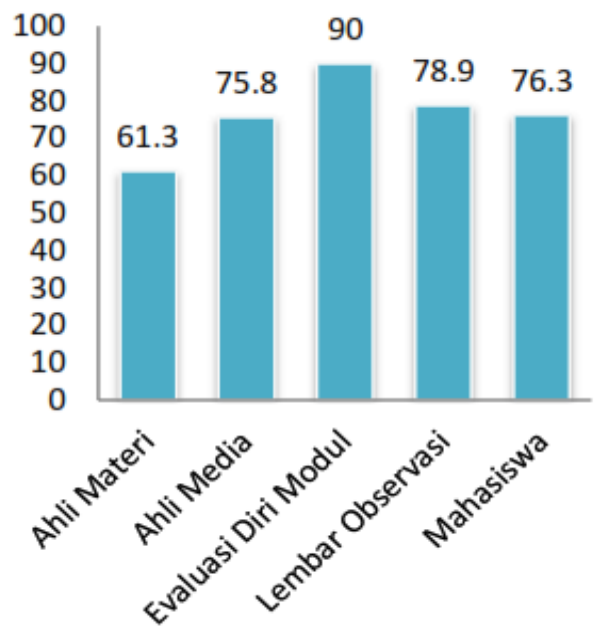

\section{Diagram 3. Rekapitulasi Aspek Penilaian Kelayakan Modul}

Hasil rekapitulasi aspek-aspek penilaian kelayakan modul yang meliputi hasil validasi ahli materi sebesar $61.3 \%$ (kategori baik), hasil validasi ahli media sebesar $75.8 \%$ (kategori baik sekali), hasil evaluasi diri modul oleh dosen sebesar 90\% (kategori baik sekali), hasil lembar observasi uji coba lapangan sebesar $78.9 \%$ (kategori baik sekali), dan hasil lembar kuesioner mahasiswa sebesar $76.3 \%$ (kategori baik sekali).

Berdasarkan hasil rekapitulasi analisis data didapatkan bahwa hasil ujicoba lapangan dan hasil kuesioner modul berada pada kategori baik sekali. Hal ini menegaskan bahwa modul yang terintegrasi keterampilan 4C layak digunakan dalam perkuliahan, sehingga mampu meningkatkan motivasi mahasiwa. Dapat disimpulkan bahwa modul yang terintegrasi keterampilan 4C layak digunakan untuk proses pembelajaran. Hal tersebut dipengaruhi oleh beberapa faktor yaitu sebagai berikut.

Pertama, modul yang terintegrasi keterampilan 4C dapat meningkatkan hasil siswa dalam belajar karena siswa dapat belajar secara mandiri. Kelebihan modul yaitu dapat digunakan untuk belajar mandiri (Purnomo \& Nugraheni, 2019). Selain hasil belajar, Modul 4C dapat meningkatakan aktivitas belajar mahasiswa, hal ini ditunjukan dengan kegiatan mahasiswa ketika belajar menggunakan modul mahasiwadapat bebas berpendapat dan bereksplorasi dalam menemukan suatu konsep atau memberikan kesimpulan ketika proses belajar berlangsung menggunakan modul tersebut. Kemudian Mahasiswa dapat mencari suatu konsep dan mendapat kesempatan untuk memberikan kesimpulan. Penggunaan modul dalam proses pembelajaran tidak hanya memandang aktifitas dosen semata, tetapi juga melibatkan mahasiswa secara aktif dalam belajar. penggunaan modul akan menciptakan proses pembelajaran yang mandiri (Nilasari et al., 2016; Rasmawan, 2018). Saat pembelajaran yang menerapkan modul sebagai bahan ajar, mahasiswa dapat secara individual menyesuaikan kecepatan belajarnya dengan kemampuan masing-masing. Mahasiswa yang memiliki kemampuan belajar cepat akan menyelesaikan pembelajaran lebi dahulu dibandingkan dengan 
temannya tanpa hambatan dari temannya yang lebih lambat. Modul dirancang untuk belajar mandiri karena modul dilengkapi dengan petunjuk belajar. penggunaan modul akan memudahkan siswa dalam memahami materi, karena siswa akan lebih mudah menyesuaikan diri dalam menerima materi pembelajaran (Gita, Samara, 2018; Irwandani et al., 2017). Penelitian yang dilakukan oleh Jamilah, Jampel, \& Parmiti (2017) menyatakan bahwa keunggulan dan kelebihan modul dalam proses pembelajaran adalah mampu memfasilitasi dan mengakomodasi kemampuan siswa untuk belajar secara mandiri tanpa tergantung pada guru.

Kedua, modul yang terintegrasi keterampilan 4C dapat meningkatkan motivasi siswa dalam belajar karena tampilan modul dan pengemasan modul yang menarik. Kelebihan modul yang dikembangkan yaitu adanya perpaduan materi pembelajaran dan gambar sehingga menambah minat mahasiswa dalam belajar. (Sudarma, I.K. (2015) menyatakan bahwa keterbacaan dan kesesuan teks akan lebih mudah diterima oleh inderi penglihatan sehingga pesan dapat tersampaikan kepada siswa dengan baik. pengemasan modul pembelajaran yang menarik akan meningkatkan motivasi siswa dalam belajar sehingga memberikan dampak pada hasil belajar yang meningkat (Gita, Samara, 2018; Novita, Sukmanasa, \& Pratama, 2019). Kemudahan penggunaan modul dan tampilan modul yang menarik akan meningkatkan motivasi siswa dalam belajar. Selain itu penggunaan bahasa yang komunikatif juga memudahkan siswa dalam memahami materi pembelajaran. Penelitian yang dilakukan oleh Diantari et al., (2018) juga menyatakan bahwa kemudahaan penggunaan E-modul akan memberi kenyamanan siswa dalam mengakses materi ajar secara mandiri. Dapat disimpulkan bahwa kemudahan penggunaan, tampilan menarik, dan bahasa komunikatif akan memberikan kenyamanan bagi siswa dalam belajar sehingga akan meningkatkan motivasi dan hasil belajar siswa secara signifikan.

Penelitian yang dilakukan oleh Suryanda, Ernawati, \& Maulana, (2016) menyatakan bahwa penggunaan modul dalam belajar dapat meningkatkan motivasi siswa dalam belajar sehingga hasil belajar siswa meningkat. Penelitian yang dilakukan oleh Qondias, D. Winarta, I, $\mathrm{K},(2019)$ juga menyatakan bahwa dalam mata kuliah motodologi penelitian perlu diintegrasikan dengan penedekatan saintifik. Pendekatan saintifik juga merupan salah satua spek yang terdapat pada keterampilan 4C. Penelitian yang dilakukan oleh Diantari, Damayanthi, Sugihartini, \& Wirawan (2018) menyatakan bahwa modul memberikan respon postif kepada siswa dapat meningkatkan siswa untuk belajar sehingga hasil belajar dapat tercapai secara optimal. Implikasi dari penelitian ini adalah mahasiswa lebih dimudahkan dalam belajar karena ketersediaan modul ini dapat meningkatkan motivasi mahasiswa dalam belajar sehingga berdampak positif terhadap hasil belajar mahasiswa.

\section{Simpulan dan saran}

Pengembangan modul dilakukan melalui $R \& D$, dan modul teori belajar dan pembelajaran fisika pnelitian yang terintegrasi dengan keterampilan abad 21 yaitu keterampilan 4C termasuk dalam kategori baik sekali. Dilihat dari hasil validasi ahli materi dan media, evaluasi oleh dosen teori belajar dan pembelajaran fisika metodologi pnelitian, hasil lembar kuesioner mahasiswa pendidikan fisika, serta hasil lembar observasi.

Hal tersebut juga dibuktikan dengan penilaian lembar observasi uji coba lapangan modul. Berikut hasil pengamatan yang diperoleh: pertama Mahasiswa dapat bebas berpendapat dan bereksplorasi dalam menemukan suatu konsep ketika proses belajar berlangsung menggunakan modul. Kedua Mahasiswa bersemangat dan tidak cepat bosan dalam mengerjakan Modul.

Adapun saran yang bisa disampaikan adalah, pada pengembangan modul selanjutnya diharapkan lebih detail menjelaskan integrasi dari keterampilan 4C pada modul, sehingga pada secara lebih jelas Nampak kendala yang dihadapi saat melakukan penelitian. 


\section{Ucapan Terimakasih}

Ucapan terimakasih diberikan kepada semua pihak yang mendukung penelitian ini, diantaranya adalah sekolah-sekolah yang dijadikan objek dan subyek penelitian, dan juga kepada Undiksha yang sudah memberikan hibah penelitian DIPA.

\section{Daftar Pustaka}

Abdullah, M., \& Osman, K. 2010. Scientific inventive thinking skills among primary students in Brunei. Procedia-Social and Behavioral Sciences, 7, 294-301.

Aina dan Kola Jacob. 2013. Instructional Materials and Improvisation in Physics Class: Implications for Teaching and Learning. Journal of Research \& Method in Education. 2(5):38-42

Arsad, N. M., Osman, K., \& Soh, T. M. T. 2011. Instrument development for 21st century skills in Biology. Procedia-Social and Behavioral Sciences, 15, 1470-1474.

Ary, Donald., Jacobs, Lucy Cheser., Sorensen Christine. 2010. Introduction to Research in Education (Eighth Edition). Wadshwort: Belmoth CA.

Brown, B. 2015. Twenty First Century Skills: A Bermuda College. Twenty First Century Skil, 58-64

Ben,K Daniel. 2017. Contestable Professional Academic Identity Of Those Who Teach Research Methodology, International Journal of Research \& Method in Education, DOI:10.1080/1743727X.2017.136951, 1-15. 38.

Cohen, Luis., Manion, Lawrence \& Marison, Keith. 2007. Research Method in Education. Routledge: New York

Dick, W., Carey, L., \& Carey, J. (2005). The systematic design of instruction. Boston: Pearson.

Daniel, B., Kumar, V., Omar, N. 2017. Postgraduate Conception of Research Methodology: Implications for Learning and Teaching. International Journal Of Research \& Method in Education. DOI: 10.1080/1743727X.2017.1283397, 1-17.

Dantes, Nyoman. 2012. Metodologi Penelitian. Yogyakarta: CV Andi Offset

Darby, N.M. \& Rashid, A.M. 2017. Critical Thinking Disposition: The Effects of InfusionApproach in Engineering Drawing. Journal of Education and Learning. Vol. 6, 205311. 24.

Egan, A., Maguire, R., Christophers, L., \& Rooney, B. 2017. Developing creativity in higher education for 21 st century learners: A protocol for a scoping review. International Journal of Educational Research. (8)2, 21-27.

Ennis, R. H. 2011. The Nature of Critical Thinking: An Outline of Critical Thinking Dispositions and

Abilities. http://faculty.education.illinois.edu/rhennis/documents/TheNatureofCriticalThinking 5171 1_000.pdf), diakses tanggal 07 Agustus 2019

Elioz Murat. 2016. Communication Skills and Learning in Impaired Individuals. Universal Journal of Educational Research 4(11): 2589-2594, Brown, B. 2015. Twenty First Century Skills: A Bermuda College. Twenty First Century Skil, 58-64

Florence Martin. 2011. Instructional Design And The Importance Of Instructional Alignment. Community College. Journal of Research and Practice. 35(5): 955-972

Greenstein, L. 2012. Assessing 21st Century Skills: A Guide to Evaluating Mastery and Authentic Learning. California: Corwin.

Greenstein, L. 2012. Assessing 21st Century Skills: A Guide to Evaluating Mastery and Authentic Learning. California: Corwin.

Guo, Z. 2016. The Cultivation of 4C's in China Critical Thinking, Communication,. International Conference on Education, Management and Applied Social Science. 3(5)1-4.

Heinich, R., Molenda, M., Russel, J.D \& Smaldino, S.E. 2002. Instructional Media and Technologies for Learning. Edisi 7. Merril Prentice Hall. New Jersey-USA.

Hill, G. 2011. Ten Principles that Drive Effective Collaboration. In Beyerlein, M.M., \& Harris, C. (Eds.), Guiding The Journey to Collaborative Work Systems 
Jasna Mazgon and Damijan Stefanc. 2012. Importance Of The Various Characteristics Of Educational Materials: Different Opinions, Different Perspectives. The Turkish Online Journal of Educational Technology. 11(3): 174-188

Kivunja, C. 2014. Innovative pedagogies in higher education to become effective teachers of 21st century skills: unpacking the learning and innovations skills domain of the new learning paradigm. International Journal of Higher Education, 3(4), 37-45. 31.

Leen, C.C., Hong, H., Kwan, F.F.H. \& Ying, T.W. 2014. Creative and Critical Thinking in Singapore Schools. Singapore: National Institute of Education, Nanyang Technological University.

Mardalis. 2010. Metode Penelitian. Jakarta: Bumi Aksara.

Martono, N. 2012. Metode Penelitian Kuantitatif. Jakarta: PT Raja Grafindo Persada.

Matthew. C Nwike. 2013. Effects of Use of Instructional Materials on Students Cognitive Achievement in Agricultural Science. Journal of Educational and Social Research. 2(5): 103-107

Merga, M.K. 2019. Collaborating With Teacher Librarians to Support Adolescents' Literacy and Literature Learning. Journal of Adolescent \& Adult Literacy, 63 (1) 65-72

Moleong. 2014. Metode Penelitian Kualitatif. Bandung: PT Remaja Rosdakarya.

National Education Association. 2010. Preparing 21st century students for a global society: An educators guide to the "Four Cs". http://www.nea.org/assets/docs/A-Guide-to-FourCs.pdf (Diakses 5 Agustus 2019)

Ozturk, B.K and Degiztanlionglu, B.E. 2018. Pre-service Turkish Teachers' Metaphorical Perceptions Regarding the Concepts of "Instructional Technology" and "Teaching Material". Universal. Journal of Educational Research. 6(5): 811-822

Osman, K., Hiong, L. C., \& Vebrianto, R. 2013. 21st Century Biology: An Interdisciplinary Approach Of Biology, Technology, Engineering And Mathematics Education. ProcediaSocial and Behavioral Sciences, 102, 188-194.

Prastowo, andi. 2011. Panduan Kreatif Membuat Bahan Ajar Inovatif. Jogjakarta: Diva Press

Pemerintah Republik Indonesia. UU No 12 Tahun. 2012. Tentang Pendidikan Tinggi. Jakarta: Presiden RI Peraturan Menteri Pendidikan Nasional. 2008. Tentang Buku. Jakarta: Menteri Pendidikan Nasional

Qondias, D. Winarta, I, K, A. Siswanto. 2019. Pengembangan Bahan Ajar Berbasis Pendekatan Saintifik pada Mata Kuliah Metodologi Penelitian. Jurnal Penelitian dan Pengembangan Pendidikan. Vol. 3(2): 145-148.

Tanyanyiwa, V. I., \& Mutambanengwe, B. 2015. Department Involvement in Instructional Materials Development for ODL Study at the Zimbabwe Open University (ZOU). Journal of Learning for Development, 2(2): 165-174

Trilling, B \& Fadel, C. 2009. 21st Century Skills: Learning for Life in Our Times. SanFrancisco: Jossey-Bass.

Wrahatnolo and Munoto. 2018. 21st centuries skill implication on educational system. The Consortium of Asia-Pacific Education Universities (CAPEU): doi:10.1088/1757899X/296/1/012036

Zubaidah, S., Corebima, A.D., \& Mistianah. 2015. Asesmen Berpikir Kritis Terintegrasi Tes Essay. Prosiding Simposium on Biology Education, Jurusan Biologi FKIP Universitas Ahmad Dahlan Yogyakarta, 4-5 April 2015. 